\title{
Historical changes in the macrophyte community of a Norwegian softwater lake
}

\author{
Peter Spierenburg • Jan G. M. Roelofs • \\ Thorbjørn J. Andersen • André F. Lotter
}

Received: 26 August 2009/ Accepted: 4 July 2010/Published online: 18 July 2010

(C) The Author(s) 2010. This article is published with open access at Springerlink.com

\begin{abstract}
Changes in macrophyte communities have occurred over the past decades in many oligotrophic softwater lakes with low carbon availability. Slowgrowing isoetid species have been replaced by fastergrowing elodeid species. Commonly, these changes are explained by anthropogenic nutrient enrichment or acidification of the lake water. Here we present a multi-proxy study in which we analysed plant macrofossils, pollen and spores, as well as sedimentological data from several cores taken from a SW Norwegian softwater lake. Our results indicate that the elodeid macrophyte Callitriche hamulata first appeared in
\end{abstract}

P. Spierenburg $(\bowtie) \cdot$ A. F. Lotter

Institute of Environmental Biology, Palaeoecology,

Laboratory of Palaeobotany and Palynology, Utrecht

University, Budapestlaan 4, 3584 CD Utrecht,

the Netherlands

e-mail: p.spierenburg@uu.nl

\author{
A. F. Lotter \\ e-mail: a.f.lotter@uu.nl
}

\section{J. G. M. Roelofs}

Department of Aquatic Ecology and Environmental Biology, Radboud University Nijmegen, Heyendaalseweg 135, 6525 AJ Nijmegen, the Netherlands

e-mail: j.roelofs@science.ru.nl

\section{T. J. Andersen}

Department of Geography and Geology, University

of Copenhagen, Øster Voldgade 10, Copenhagen 1350,

Denmark

e-mail: tja@geo.ku.dk this lake in the 1970s. Proliferation of $C$. hamulata occurred in the 1990s, replacing the hitherto dominant submerged Isoëtes macrophyte vegetation. Independent lines of evidence, such as diatom-inferred TP and $\mathrm{pH}$ reconstructions, showed no change during the past 200 years, therefore ruling out both acidification and phosphorus enrichment of the lake as possible causes for the observed change in the macrophyte community. Alternatively, expansion of Callitriche at the expense of Isoëtes may have been related to increased aquatic carbon availability, although nitrogen enrichment may also have been important.

Keywords Macrophyte communities - $\mathrm{pH}$. Total phosphorus · Softwater lakes · Isoëtes · Invasive species

\section{Introduction}

Softwater lakes are characterized by nutrient-poor waters with low alkalinity and carbon content. Commonly, the macrophyte community of pristine softwater lakes is dominated by species with an isoetid growing form, such as Isoëtes L., Lobelia dortmanna L., and Littorella uniflora (L.) Aschers. These slowgrowing macrophyte species possess several adaptations to maintain stable populations in oligotrophic, carbon-poor softwater lakes. Several adaptations help isoetids overcome carbon stress, such as the ability to utilize pore water $\mathrm{CO}_{2}$ and a crassulacean acid 
metabolism (CAM), as observed in several Isoëtes species and L. uniflora (Keeley 1998).

During the past few decades, fast-growing elodeid species, such as Callitriche hamulata Kütz. ex W.D.J. Koch and Myriophyllum alterniflorum D.C. have appeared and proliferated in some softwater lakes, regularly outcompeting the slower-growing isoetid species (Roelofs 1983). It is, however, unclear what factors are responsible for the appearance and spread of these elodeids. In many lakes, changes in macrophyte community structure have been linked to eutrophication (Sayer et al. 1999) or acidification (Grahn 1977; Roelofs 1983). In pristine softwater lakes, however, macrophyte production is often carbon-limited (Murphy 2002). More specifically, most macrophytes are likely only limited by $\mathrm{CO}_{2}$, because $\mathrm{HCO}_{3}{ }^{-}$ concentrations in softwater lakes are generally $<200$ $\mu \mathrm{mol} 1^{-1}$, which is insufficient to contribute significantly to the carbon requirements for photosynthesis of potential $\mathrm{HCO}_{3}{ }^{-}$-using macrophytes (Madsen et al. 1996). Therefore, carbon enrichment in the water column might be responsible for the observed shifts in softwater macrophyte communities. Previous studies in softwater lakes showed, for instance, that carbon enrichment triggered substantial expansions of Juncus bulbosus L. (Lucassen et al. 1999). Carbon enrichment in softwater lakes can be related to rising inputs of dissolved organic carbon (DOC) from terrestrial sources, due to factors such as increased temperature and changes in hydrology (Hudson et al. 2003; Evans et al. 2005). Because $\mathrm{CO}_{2}$ is formed when DOC is degraded by microbial activity or photo-oxidation, a rise in DOC levels is generally also accompanied by a rise in $\mathrm{CO}_{2}$ availability (Cole et al. 2002).

In this study, we assessed the importance of lake water $\mathrm{CO}_{2}$ and nutrient enrichment to the observed appearance and proliferation of elodeids such as C. hamulata in softwater lakes. Using a palaeolimnological approach, we obtained data on the past composition of the macrophyte community and lake water chemistry. We investigated several sediment cores from a Norwegian oligotrophic softwater lake that, at present, is characterized by dense patches of C. hamulata and has had extensive isoetid communities in the past. We used multiple independent proxies that provided several independent lines of evidence (Birks and Birks 2006; Lotter 2003), which allowed us to discern the potential drivers behind the apparent changes in the macrophyte community.
Study site

Lake Steigatjørna is a small, oligotrophic softwater lake with organic-rich sediments, located in southwestern Norway (Rogaland County, $58^{\circ} 25^{\prime} 31.4^{\prime \prime} \mathrm{N}$ $6^{\circ} 16^{\prime} 39.0^{\prime \prime}$ E, $137 \mathrm{~m}$ a.s.1., Table 1; Fig. 1). Regional climate is characterized by mean July and January temperatures of 15 and $3{ }^{\circ} \mathrm{C}$, respectively, and mean annual precipitation of $1,650 \mathrm{~mm}$, with most of the precipitation falling during summer (MET 2009).

The bedrock of the lake basin and the western catchment consists mainly of anorthosite. East of the

Table 1 Catchment, climate, and water chemistry data for Lake Steigatjørna

\begin{tabular}{|c|c|c|}
\hline Surface area & $40,910 \mathrm{~m}^{2}$ & \\
\hline Altitude & $137 \mathrm{~m}$ a.s.1. & \\
\hline Longitude & $58^{\circ} 25^{\prime} 31^{\prime \prime} \mathrm{N}$ & \\
\hline Latitude & $6^{\circ} 16^{\prime} 39^{\prime \prime} \mathrm{E}$ & \\
\hline Maximum depth & $18.5 \mathrm{~m}$ & \\
\hline January temperature & $3.2^{\circ} \mathrm{C}$ & \\
\hline July temperature & $15.0^{\circ} \mathrm{C}$ & \\
\hline Mean annual temperature & $8.6^{\circ} \mathrm{C}$ & \\
\hline \multirow[t]{2}{*}{ Mean annual precipitation } & $1,599 \mathrm{~mm}$ & \\
\hline & Oct 2006 & May 2007 \\
\hline Alkalinity (meq $1^{-1}$ ) & 0.047 & na \\
\hline $\mathrm{pH}$ & 5.1 & 5.5 \\
\hline $\mathrm{CO}_{2}\left(\mu \mathrm{g} \mathrm{l}^{-1}\right)$ & 2,700 & 1,400 \\
\hline $\mathrm{HCO}_{3}^{-}\left(\mu \mathrm{g} \mathrm{1^{-1 } )}\right.$ & 200 & 300 \\
\hline $\mathrm{TP}\left(\mu \mathrm{g} \mathrm{P} 1^{-1}\right)$ & na & 6 \\
\hline $\mathrm{PO}_{4}^{2-}\left(\mu \mathrm{g} \mathrm{P}^{-1}\right)$ & na & 3 \\
\hline $\mathrm{TN}\left(\mu \mathrm{g} \mathrm{N}^{-1}\right)$ & na & 392 \\
\hline $\mathrm{NO}_{3}^{-}\left(\mu \mathrm{g} \mathrm{N}^{-1}\right)$ & na & 336 \\
\hline $\mathrm{NH}_{4}^{+}\left(\mu \mathrm{g} \mathrm{N} 1^{-1}\right)$ & na & 56 \\
\hline $\mathrm{K}\left(\mu \mathrm{g}^{-1}\right)$ & 442 & 477 \\
\hline $\mathrm{Ca}\left(\mu \mathrm{g} \mathrm{1^{-1 }}\right)$ & 982 & 1,592 \\
\hline $\mathrm{S}\left(\mu \mathrm{g}^{-1}\right)$ & 755 & 1,362 \\
\hline $\mathrm{Si}\left(\mu \mathrm{g} \mathrm{1^{-1 } )}\right.$ & 282 & 766 \\
\hline $\mathrm{Al}\left(\mu \mathrm{g} \mathrm{1^{-1 }}\right)$ & 112 & 146 \\
\hline $\mathrm{Fe}\left(\mu \mathrm{g} \mathrm{1^{-1 }}\right)$ & 202 & 175 \\
\hline $\operatorname{Mg}\left(\mu \mathrm{g}^{-1}\right)$ & 499 & 1,039 \\
\hline $\operatorname{Mn}\left(\mu \mathrm{g}^{-1}\right)$ & 3 & 17 \\
\hline $\mathrm{Zn}\left(\mu \mathrm{g} \mathrm{l}^{-1}\right)$ & 3 & 10 \\
\hline
\end{tabular}

The climate data are from the period 2003-2007 (MET 2009). Water samples were taken at midday in $30 \mathrm{~cm}$ water depth 


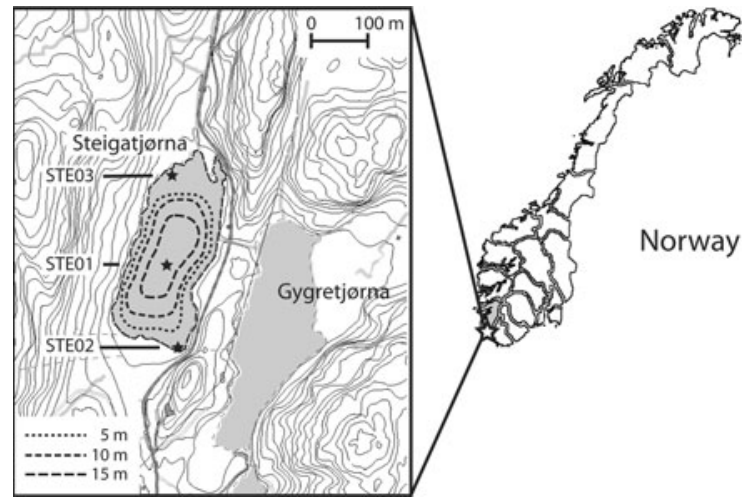

Fig. 1 Location of Steigatjørna, topographic map including bathymetry of the lake basin, and the locations of the sediment cores (stars)

lake is a mix of mangerite, gabbro, gneiss, and amphibolite. Farther east and in the northern catchment area, the bedrock is dominated by monzonite. These rocks are either directly exposed, or are covered by a relatively thin litter layer. Steigatjørna is fed by rainwater and by streams from several lakes to the north and is connected to other downstream lakes to the south. Several small meadows in the Steigatjørna catchment are used for small-scale sheep grazing and a road ( $\mathrm{Rv}$ 501) runs along the eastern shore.

To counteract the effects of acid deposition, largescale liming applications, including direct liming of lakes, were undertaken in Norway and Sweden during the past 30 years. Steigatjørna and the connected upstream lakes were, however, not part of this liming program (Ministry of Environment), whereas smallscale liming of the catchment by local farmers may have occurred.

The macrophyte community in the littoral of Steigatjørna is characterised by widespread patches of Callitriche hamulata. Furthermore, Isoëtes echinospora Durieu, Isoëtes lacustris L., and Lobelia dortmanna are present. An overview of the presentday macrophyte flora is given in Table 2.

\section{Materials and methods}

In May 2007, three sediment cores were taken from Steigatjørna, one profundal core (STE01) and two littoral cores (STE02, STE03) (Fig. 1). The profundal
Table 2 Most important macrophyte species present in Steigatjørna in 2006-2007

\begin{tabular}{|c|c|c|}
\hline Habitat & Species & Abundance \\
\hline \multirow[t]{10}{*}{ Water } & Isoëtes echinospora & ++++ \\
\hline & Isoëtes lacustris & ++++ \\
\hline & Callitriche hamulata & +++ \\
\hline & Nymphaea candida/lutea & +++ \\
\hline & Equisetum fluviatile & ++ \\
\hline & Hippuris vulgaris & ++ \\
\hline & Juncus bulbosus & + \\
\hline & Lobelia dortmanna & + \\
\hline & Myriophyllum alterniflorum & + \\
\hline & Sparganium angustifolium & + \\
\hline \multirow[t]{8}{*}{ Shore } & Menyanthes trifoliata & ++++ \\
\hline & Potentilla palustris & ++++ \\
\hline & Glyceria fluitans & +++ \\
\hline & Eriophorum angustifolium & ++ \\
\hline & Calla palustris & + \\
\hline & Caltha palustris & + \\
\hline & Carex rostrata & + \\
\hline & Juncus effusus & + \\
\hline
\end{tabular}

Abundance: $+=$ present; $++=$ locally abundant; $+++=$ locally dominant; $++++=$ dominant

core had a length of $45 \mathrm{~cm}$ and was taken at $18.2 \mathrm{~m}$ water depth in the deepest part of the basin with an UWITEC gravity corer $(\varnothing 6 \mathrm{~cm})$. The littoral cores were $40 \mathrm{~cm}$ (STE02) and $30 \mathrm{~cm}$ (STE03) long and were taken at $1 \mathrm{~m}$ water depth, using a Kajak corer $(\varnothing 8 \mathrm{~cm})$. All cores were extruded in the field in $1 \mathrm{~cm}$ increments and stored cold and dark before further analyses. For all cores, water content and loss on ignition at $550^{\circ} \mathrm{C}\left(\mathrm{LOI}_{550}\right)$ were determined following Heiri et al. (2001). Carbon and nitrogen content of freeze-dried sediment of all cores was determined on an elemental analyzer (EA 1110, Carlo Erba; Thermo Fisher Scientific, Waltham, U.S.A.). For the $\mathrm{Si}, \mathrm{Al}, \mathrm{Fe}, \mathrm{Mg}$, and $\mathrm{Ca}$ content, freeze-dried sediment was ground and moulded to beads at $1,200^{\circ} \mathrm{C}$ (Herzog fusion machine HAG-S, Osnabrück, Germany). After cooling, the elemental composition of the beads was measured using an ARL 9200 X-ray fluorescence spectrometer (Thermo Scientific, Waltham, U.S.A).

For the dating of core STE01, the activity of ${ }^{210} \mathrm{~Pb}$, ${ }^{226} \mathrm{Ra}$, and ${ }^{137} \mathrm{Cs}$ was measured by gamma spectrometry 

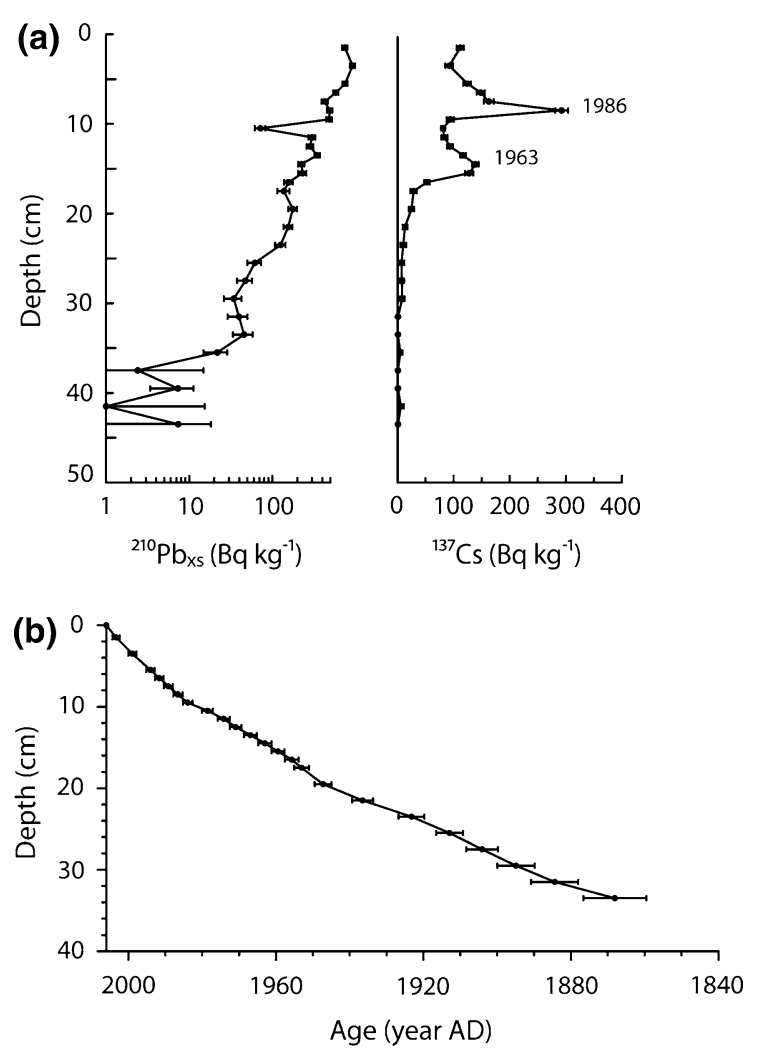

Fig. $2 \mathbf{a}^{210} \mathrm{~Pb}$ and ${ }^{137} \mathrm{Cs}$ activities in core STE01 b Depth age model for core STE01

on freeze-dried sediment on a Canberra low-background Germanium well-detector. ${ }^{210} \mathrm{~Pb}$ was measured via its gamma-peak at $46.5 \mathrm{keV},{ }^{226} \mathrm{Ra}$ via the granddaughter ${ }^{214} \mathrm{~Pb}$ (peaks at 295 and $352 \mathrm{keV}$ ), and ${ }^{137} \mathrm{Cs}$ via its peak at $661 \mathrm{keV}$. The constant rate of supply (CRS) model (Appleby 2001) was applied to the profile using a modified method in which the activity at the bottom of the core was calculated on the basis of a regression of unsupported ${ }^{210} \mathrm{~Pb}$ versus cumulative mass depth. This procedure gives a more robust chronology, especially at the bottom of the core, compared to conventional CRS modelling. The bomb test maximum in AD 1963 was used for minor correction of the ${ }^{210} \mathrm{~Pb}$-based chronology, following the procedure described by Appleby (2001). The chronology is shown in Fig. 2. Extrapolation of the dating model shows a maximal age of $\sim 200$ years (AD 1800) for the bottom of core STE01. Cores STE02 and STE03 were correlated with STE01 based on their LOI, carbon, and nitrogen content using ANALYSERIES Version 2.0.4 (Paillard et al. 1996).
Both littoral cores (STE02, STE03) were analyzed for plant macrofossils. For this purpose, $40 \mathrm{~cm}^{3}$ of fresh sediment was taken from each $1-\mathrm{cm}$ increment and sieved through a $125-\mu \mathrm{m}$ mesh. Macrofossils were picked, identified, and counted under a Leica MZ12.5 stereomicroscope at 25-100× magnifications. Generative and vegetative parts of macrophytes were identified using Martin and Barkley (1961), Berggren (1969, 1981), Beijerinck (1976), and Cappers et al. (2006), whereas the identification of Isoëtes megaspores to species level followed Berthet and Lecocq (1977) and for Callitriche seeds, Schotsman (1954). In addition, we used the modern macrofossil reference collection of the Laboratory of Palaeobotany and Palynology.

One- $\mathrm{cm}^{3}$ fresh sediment samples from the profundal core (STE01), were spiked with Lycopodium spores and used for quantitative pollen analysis. Pollen samples were prepared with acetolysis (Bennett and Willis 2001). Pollen and spores were identified and counted under a Leica DMLS microscope at $400 \times$ magnification. Identification followed Faegri and Iversen (1989), Moore et al. (1991), and Beug (2004). When necessary, we consulted the modern reference pollen and spore collection in the Laboratory of Palaeobotany and Palynology.

Diatom slides were prepared using the sedimentation tray method (Battarbee 1973), with Naphrax ${ }^{\circledR}$ as a mounting medium. A minimum of 300 valves was counted on each slide under a light microscope at $1,000 \times$ magnification, using differential interference contrast optics. Taxonomy followed Krammer and Lange-Bertalot (1999a, b, 2000, 2004). For quantitative reconstructions, diatom percentages were square root transformed. Total phosphorus (TP) concentrations were reconstructed using a modern diatom training set with log-transformed TP from the NW European dataset, combined with the Norwegian dataset that is available from the European Diatom Database (EDDI 2009). For the diatom-inferred $\mathrm{pH}$ reconstruction, we used the Norwegian modern training set. Both TP and $\mathrm{pH}$ reconstructions were modelled using Weighted Averaging Partial Least Squares (WA-PLS) regression and calibration procedures (ter Braak and Juggins 1993) that were cross-validated using 100 bootstrap cycles in the program $\mathrm{C} 2$ version 1.5 (Juggins 2007). A summary of the models and their performances is given in Table 3 . 
Table 3 Input data and performance of diatom-based weighted averaging partial least squares (WA-PLS) pH and total phosphorus (TP) inference models

\begin{tabular}{|c|c|c|c|c|c|}
\hline & Dataset & Samples & Taxa & Range & Median \\
\hline $\mathrm{pH}$ & Norwegian & 96 & 277 & $4.3-8.3$ & 5.5 \\
\hline $\mathrm{TP}$ & Norwegian \& NW Europe & 259 & 495 & $3-646 \mu \mathrm{g} \mathrm{P} 1^{-1}$ & $36 \mu \mathrm{g} \mathrm{P} 1^{-1}$ \\
\hline Fossil data & Steigatjørna & 10 & 85 & & \\
\hline \multicolumn{6}{|c|}{ Model performance } \\
\hline WA-PLS & WAPLS components & $R_{\text {bootstrap }}^{2}$ & \multicolumn{2}{|c|}{ RMSEP } & max. bias bootstrap \\
\hline $\mathrm{pH}$ & 2 & 0.93 & \multicolumn{2}{|c|}{$0.34 \mathrm{pH}$ unit } & 0.39 \\
\hline $\mathrm{TP}$ & 2 & 0.89 & \multicolumn{2}{|c|}{$0.23 \log \mathrm{TP}$} & 0.71 \\
\hline
\end{tabular}

Modern diatom training sets originate from the European Diatom Database (EDDI 2009)

\section{Results and discussion}

\section{Chronology}

The surface sediments of core STE01 showed high contents of unsupported ${ }^{210} \mathrm{~Pb}\left(\sim 900 \mathrm{~Bq} \mathrm{~kg}^{-1}\right)$, with activities decreasing exponentially with depth (Fig. 2). The calculated flux of unsupported ${ }^{210} \mathrm{~Pb}$ is 307 $\mathrm{Bq} \mathrm{m}{ }^{-2}$ year $^{-1}$, which is at least three times higher than the estimated local atmospheric supply (Appleby 2001), indicating that the site is subject to sediment focusing. Significant activities of ${ }^{137} \mathrm{Cs}$ were found down to a depth of about $30 \mathrm{~cm}$. A distinct maximum was found at $8.5 \mathrm{~cm}$ (AD 1986, Chernobyl accident) and a broader activity peak was measured at around $15 \mathrm{~cm}$ sediment depth (AD 1963, peak in atmospheric bomb testing). Based on both ${ }^{137} \mathrm{Cs}$ and ${ }^{210} \mathrm{~Pb}$ dating, a depth-age model (Fig. 2b) was established showing that core STE01 includes sediment accumulated since the beginning of the nineteenth century.

\section{Macrophyte community changes}

Detailed analyses of macro- and micro-remains in the cores showed that the submerged macrophyte community in Lake Steigatjørna has been dominated by Isoëtes echinospora and I. lacustris for most of the past 200 years (Figs. 3, 4, 5). In profundal core STE01, relative stable accumulation rates of Isoëtes microspores were found with two minima at $c a$. AD 1850 and at $c a$. AD 1980, and a maximum between ca. AD 1950 and 1955. The maximum coincides with peaks in the accumulation rates of the diatoms (Fig. 6), as well as several other wetland species, trees and shrubs, suggesting that these elevated accumulation rates are the result of taphonomic processes. In the absence of simultaneous large changes in sediment $\mathrm{C}: \mathrm{N}$ ratio and distinct $\mathrm{Si}, \mathrm{Fe}$, or Al peaks (Fig. 7) these taphonomic processes at this time interval are not caused by the input of substantial amounts of allochthonous matter. Alternatively, the elevated accumulation rates of all biotic variables may reflect a relatively fast drop in lake level, thus lowering the location of the wave action zone, which in turn resulted in enhanced re-suspension of littoral deposits. Such re-suspension eventually led to a re-deposition of littoral matter in the deeper part of the basin, resulting in higher accumulation rates. Seeds of the elodeid Callitriche hamulata first appeared in the record in the 1970s (Figs. 4, 5) and since the 1990s their accumulation rates have increased steadily. The numbers of Isoëtes remains displayed a large decrease, especially in STE02 (Fig. 4), suggesting that $C$. hamulata replaced Isoëtes locally since the middle 1990 s.

Pollen grains of $C$. hamulata have a very thin exine and preservation of the pollen is often poor (Schotsman 1954), which may be a reason for the absence of $C$. hamulata pollen in the deep-water core. Therefore, it is not possible to make any statements about the presence of $C$. hamulata before AD 1950, i.e. during the time not covered by the littoral cores. Still, the question arises, what triggered the recent local proliferation of $C$. hamulata. Potential drivers for this change in macrophyte composition are eutrophication, acidification, or carbon enrichment. Using a multi-proxy approach, we address different mechanisms that may explain changes in macrophyte communities that often occur in softwater lakes. 


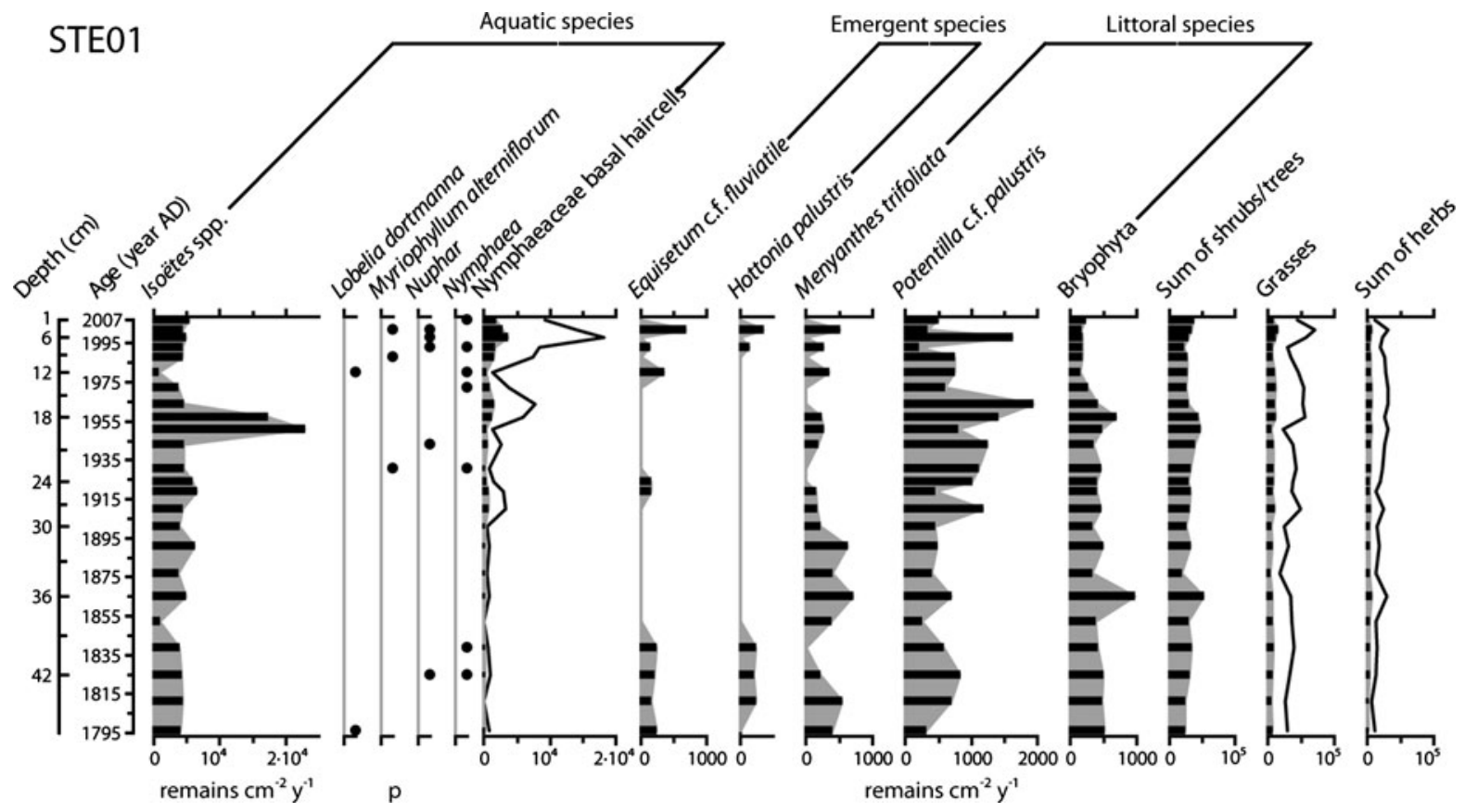

Fig. 3 Accumulation rates and presence (p) of plant micro-remains in core STE01 (black lines: $5 \times$ exaggeration). Note the different scaling of the $\mathrm{x}$-axes

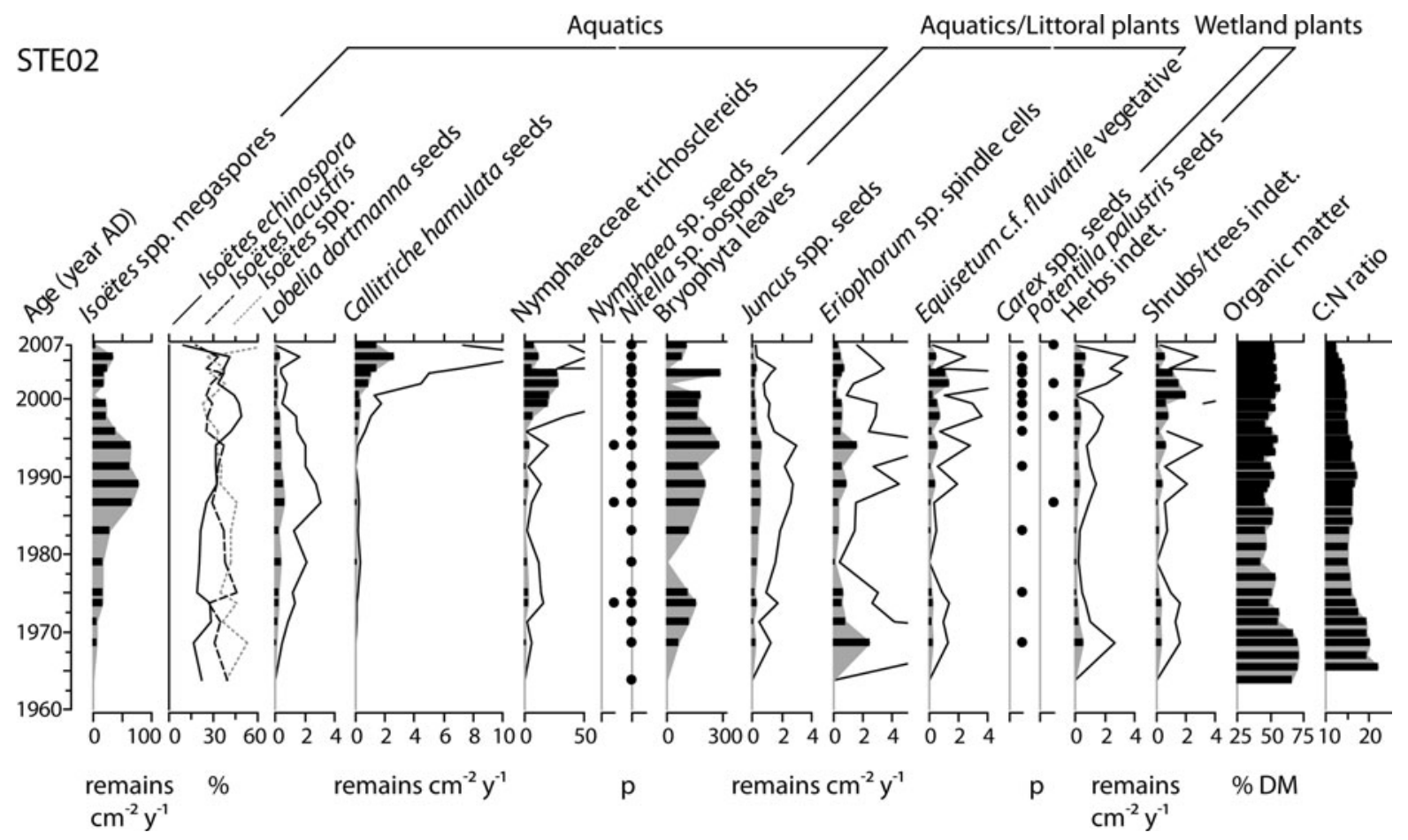

Fig. 4 Accumulation rates and presence (p) of plant macro-remains in core STE02 together with the percentage of organic matter and the $\mathrm{C}: \mathrm{N}$ ratio (mass). Note the different scaling of the $\mathrm{x}$-axes 


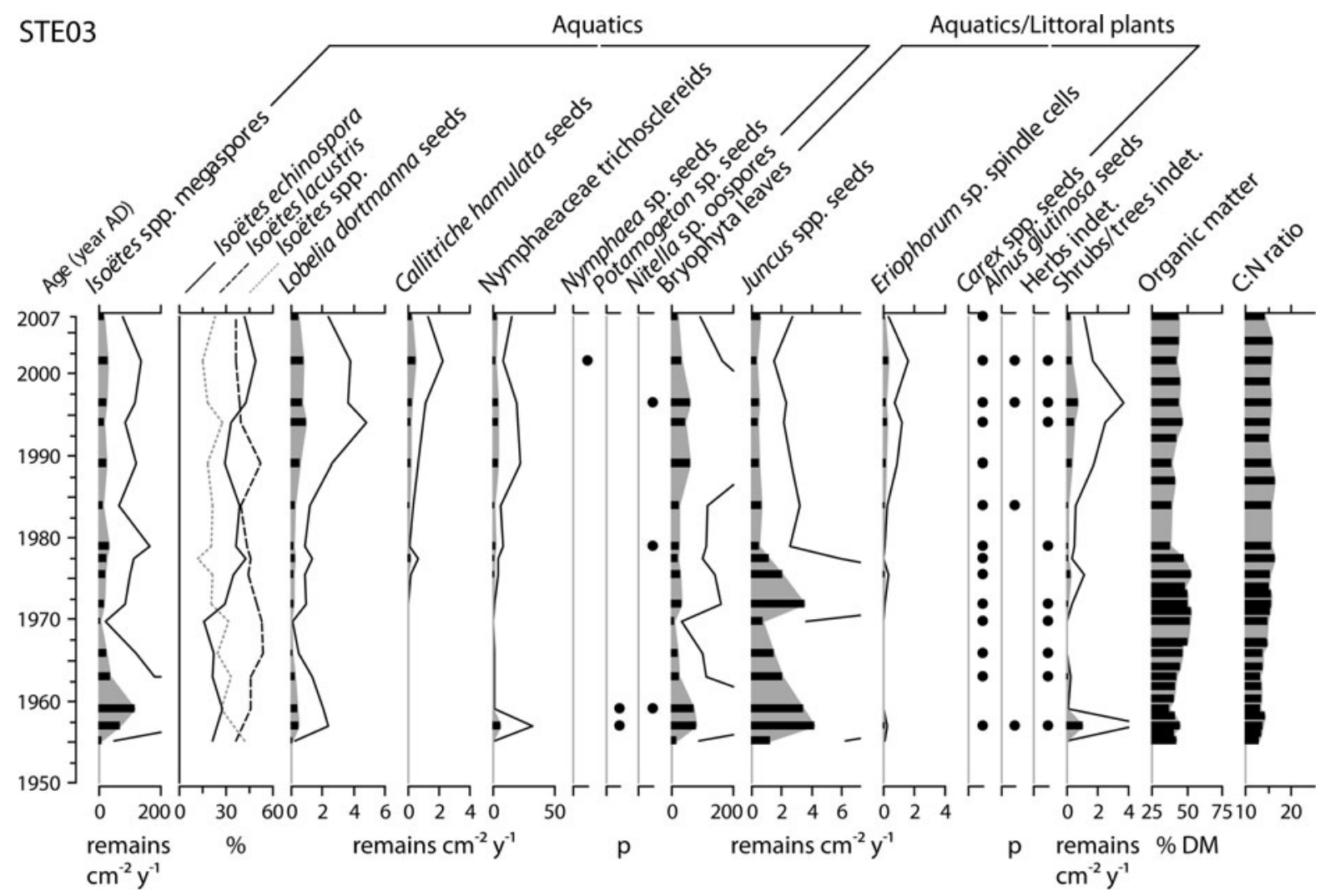

Fig. 5 Accumulation rates and presence (p) of plant macro-remains in core STE03, together with the percentage of organic matter and the $\mathrm{C}: \mathrm{N}$ ratio (mass). Note the different scaling of the $\mathrm{x}$-axes

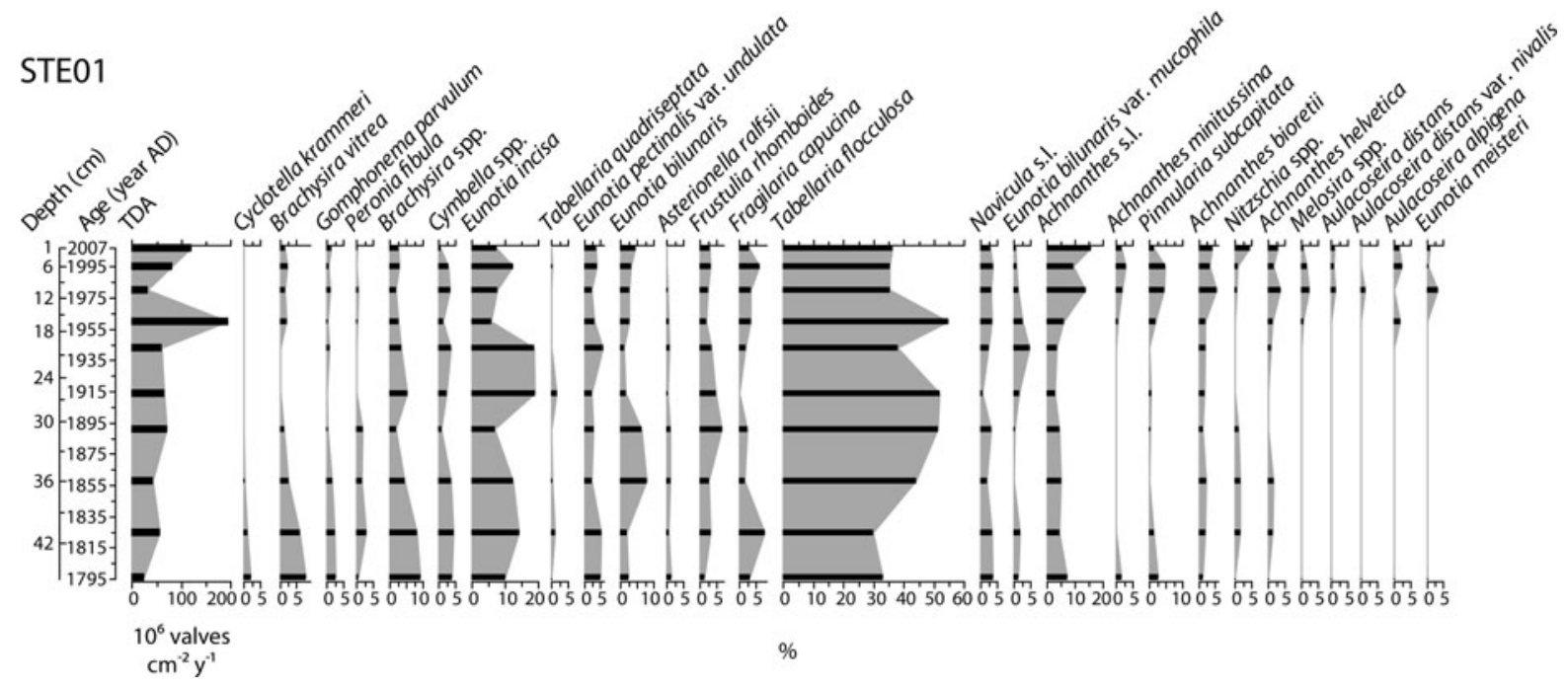

Fig. 6 Diatom percentages plotted against age for core STE01. Total diatom accumulation rate (TDA) is calculated based on the sum of all counted diatoms valves 
Fig. 7 Sediment geochemistry, diatom inferred total phosphorus (TP) and $\mathrm{pH}$ for core STE01. The C:N ratio is based on mass. Note the different scaling of the $\mathrm{x}$-axes
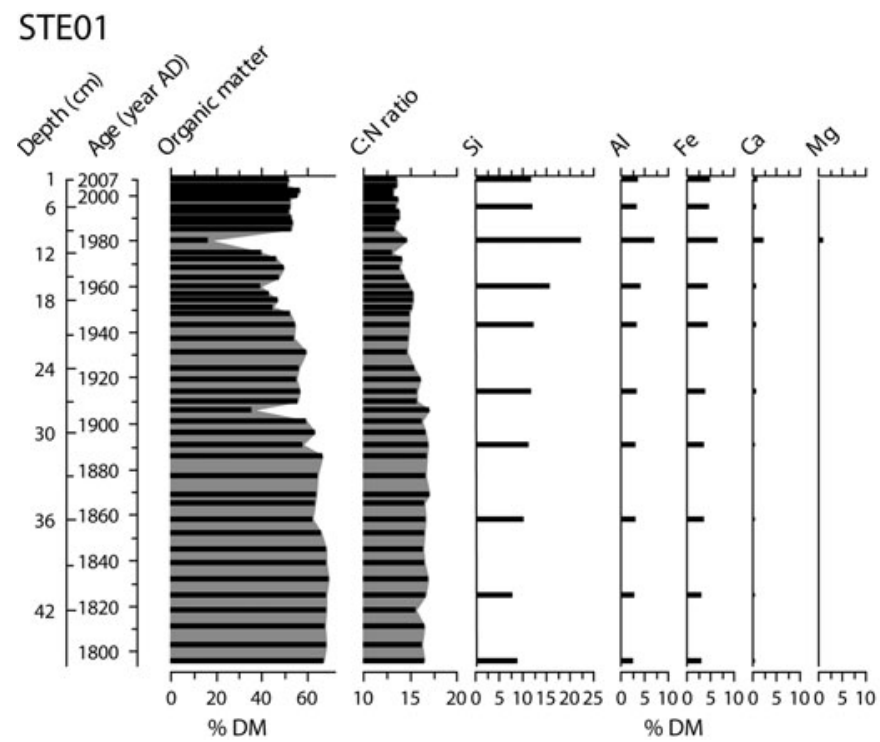

Nutrient enrichment

Spring measurements of total phosphorus (TP, $6 \mu \mathrm{g}$ $\mathrm{P}^{-1}$ ) and total nitrogen (TN, $392 \mu \mathrm{g} \mathrm{N}^{-1}$ ) in the water column (Table 1), show Steigatjørna can be classified as oligotrophic (Wetzel 2001). The present and past diatom and macrophyte assemblages are, indeed, typical for oligotrophic lakes. Throughout core STE01, the well-preserved diatom assemblages consisted of about 100 taxa and were dominated by Tabellaria flocculosa (Roth) Kützing and Eunotia incisa Gregory (Fig. 6). The latter is an acidophilous species with oligotrophic affinities (van Dam et al. 1994; Chen and Coughenour 1996), whereas T. flocculosa has a wider TP tolerance, ranging from eutrophic-mesotrophic to oligotrophic waters (Lowe 1974; Bennion 1994; Chen et al. 2008). The macrophyte community of the lake is characterized by Isoëtes lacustris, I. echinospora, and Lobelia dortmanna, which are often found in oligotrophic, clearwater lakes with low alkalinity (Murphy 2002). Besides Isoëtes micro- and megaspores, many Nymphaeaceae remains were recovered in both the profundal and the littoral cores (Figs. 2, 3, 4). The Nymphaeaceae remains accumulation rates increased after AD 1900. Nymphaeaceae abundance is often related to mesotrophic conditions, but many Norwegian oligotrophic waters also contain these floatingleaved plants. This likely reflects the presence of organic-rich, mesotrophic sediments from which these plants can acquire nutrients through their extensive root system (Ellenberg et al. 1991). Field observations of Menyanthes trifoliata L., Potentilla palustris (L.) Scop., Equisetum fluviatile L., and Hottonia palustris L. also point to organic-rich telmatic and littoral lacustrine deposits (Ellenberg et al. 1991). Hottonia palustris and M. trifoliata pollen were present in profundal core STE01 (Fig. 3), indicating that these species were also abundant in the past. The Potentilla pollen and Equisetum spores most likely originate from the still abundant P. palustris and E. fluviatile.

Diatom-inferred TP values (Fig. 7) remained stable and low, at $c a .10 \mu \mathrm{g} \mathrm{P} 1^{-1}$ during the past 200 years. The TP model we used shows a high cross-validated $R^{2}$, and a low RMSEP (Table 3). Tabellaria flocculosa, the dominant diatom species (Fig. 6), occurs at a TP range of 3.8-33.4 $\mu \mathrm{g}^{-1}$ (mean 10.5) in the modern training dataset. Bennion et al. (2001) and Sayer (2001) point out that caution in the interpretation of TP inference models is appropriate if diatom assemblages are dominated by periphytic taxa. Periphytic diatoms tend to have a wider TP tolerance and are also dependent on other factors, such as light availability and the presence of a suitable substratum. Therefore, periphyton-dominated assemblages may lead to the inference model being less sensitive to changes in TP. Despite the assemblages containing many periphytic diatoms, such an effect is minimal in our study because the 

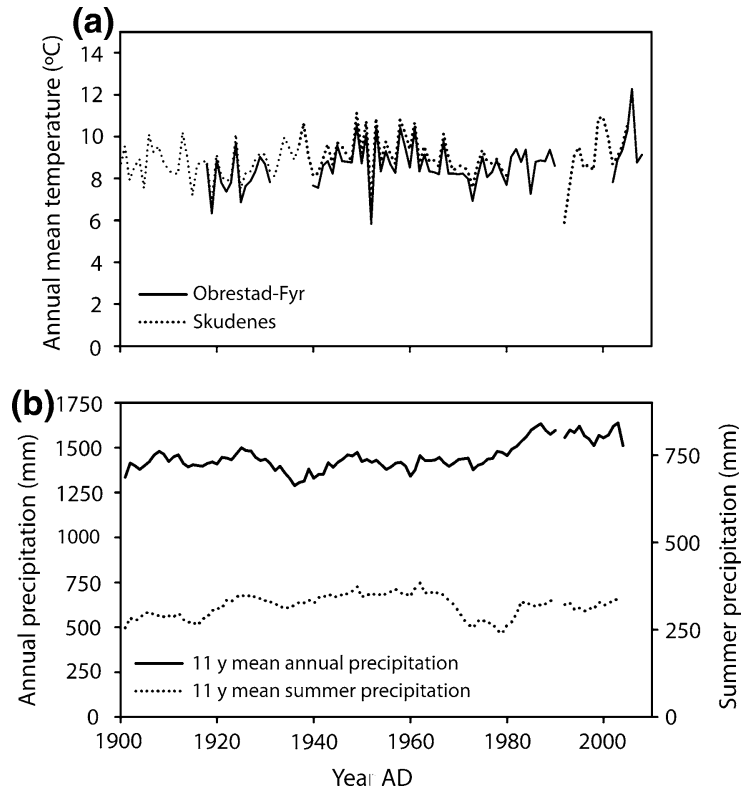

Fig. 8 a Annual mean air temperature measured at weather stations Obrestad-Fyr (49 km from Steigatjørna, $1 \mathrm{~km}$ from the coastline of Norway) and Skudenes (99 km, $0.5 \mathrm{~km})$, b 11-year running means of mean annual (left $\mathrm{x}$-axis) and summer precipitation (right $\mathrm{x}$-axis) measured at the weather station Egersund (16 km, $5 \mathrm{~km}$ ) (MET 2009)

changes in down-core diatom assemblages are small (Fig. 6). Moreover, there is close agreement between the diatom-inferred TP of the top sample (Fig. 7) and the measured lake water TP in spring (Table 1) as well as measured TP values of 19 softwater lakes in the vicinity of Steigatjørna (mean $\pm \mathrm{SE}=9.3 \mu \mathrm{g} \mathrm{P}$ $1^{-1} \pm<0.05$, Lucassen et al. 2009). Low and stable TP concentrations in this rainwater-fed lake are likely the result of the high amount of precipitation in this region (Fig. 8), resulting in a low water residence time. Furthermore, the lake's catchment is used only for small-scale pasturing, so that the external phosphorus loading is expected to be low.

Although the measured nitrogen content of Steigatjørna was low $\left(392 \mu \mathrm{g} \mathrm{N}{ }^{-1}\right.$, mainly as $\mathrm{NO}_{3}$, Table 1), it is higher than in other softwater lakes in the region, which have spring-summer TN concentrations of about $150 \mu \mathrm{g} \mathrm{N}^{-1}$ (Roelofs et al. 1994; Lucassen et al. 2009). Nitrogen levels in Steigatjørna could have become slightly elevated due to increased nitrogen inputs originating from increased fertilization of the catchment pastures. Ongoing airborne nitrogen deposition might also have increased lake nitrogen levels, but would also have affected other lakes in the
Rogaland region, which is not the case. In the absence of a TN inference model, we cannot estimate variations in the nitrogen content of the lake in the past. In the diatom assemblages, however, no nitrogen enrichment is apparent, and indicators for nitrogen enrichment such as Asterionella formosa Hassall, Fragilaria crotonesis Kitton, Navicula cryptocephala Kützing, Navicula pupula Kützing, or Stephanodiscus hantzschii Grunow (Wolfe et al. 2001; Rühland and Smol 2002) are absent from the core. Very low TP concentrations, however, may cause strong phosphorus limitation, which could inhibit effects of nitrogen enrichment on diatom assemblages.

\section{Acidification}

Since the onset of the industrial revolution in the nineteenth century, deposition of acidifying chemicals such as $\mathrm{H}_{2} \mathrm{SO}_{4}$ and $\mathrm{HNO}_{3}$ has increased, especially in northwestern and eastern Europe. During the 1970s and 1980s, maximal deposition rates were measured, after which deposition, mainly of sulphuric acid, was reduced to much lower levels. In the region of Rogaland, where our study site is located, the amount of past acid deposition often exceeded the local buffering capacity, resulting in soil and surface water acidification. Today, some recovery is observed, although nitrogen deposition is still relatively high in relation to the buffering capacity of the soils (Larssen and Høgåsen 2003).

The diatom assemblages of Steigatjørna (Fig. 6) are representative of slightly acidic, nutrient-poor surface waters. The diatom-inferred $\mathrm{pH}$ of Steigatjørna is slightly below pH 6 and is, within model error, rather stable throughout the past 200 years (Fig. 7). Diagnostics of the $\mathrm{pH}$-inference model indicate good performance (Table 3 ) and the measured $\mathrm{pH}$ of the lake (5.5, Table 1) corresponds well with the diatom-inferred $\mathrm{pH}$ for the surface sediment sample (5.7, Fig. 7).

Dominance of $T$. flocculosa is less pronounced in the lowermost samples of core STE01 ( $c a$. AD 1800-1870, Fig. 6), while diatoms such as Brachysira vitrea (Grunow) Ross in Hartley, Gomphonema parvulum (Kützing) Kützing, Fragilaria capucina Desmazières, and Cyclotella krammeri Håkansson gradually decline towards the core top. These diatom assemblages are typical for Scandinavian lakes that are not anthropogenically acidified or limed, as has been 
shown for Swedish lakes (Renberg et al. 1993). At the onset of the twentieth century, the diatom-inferred $\mathrm{pH}$ suggests slightly more acidic conditions for a short period (Fig. 7), as denoted by the increase in E. incisa, Tabellaria quadriseptata Knudson, T. flocculosa, and Frustulia rhomboides (Ehrenberg) De Toni. The simultaneous disappearance of C. krammeri, $B$. vitrea, and G. parvulum (Fig. 6) may also be related to this slight drop in diatom-inferred $\mathrm{pH}$ to 5.5 (Renberg et al. 1993; Cameron 1995). The inferred $\mathrm{pH}$ decrease in this period is, however, still within the error range of the inference model and may also be within the natural variability of the system. After this slight temporary drop, the lake reverted to earlier $\mathrm{pH}$ levels and stayed more or less stable around inferred values of 5.8. From the late 1940s onwards the accumulation rates of Achnanthes s.l., including Achnanthes minutissima Kützing, increased. Achnanthes minutissima has been linked to direct liming of acidified lakes (Renberg and Hultberg 1992; Renberg et al. 1993). However, in Steigatjørna the appearance of A. minutissima is probably not related to liming because other liming indicators such as Cymbella microcephala Grunow or Fragilaria ulna (Nitzsch) Lange-Bertalot are absent from the fossil diatom assemblages. In addition, as an effect of liming, increased concentrations of $\mathrm{Ca}$ and $\mathrm{Mg}$ in the sediment would be expected, but have not been observed in the cores (Fig. 7). Alternatively, the increase in the abundance of different Achnanthes s.l. species, together with for instance Pinnularia subcapitata Gregory and Aulacoseira spp., is probably related to increased macrophyte coverage, providing epiphytic diatoms with a larger area of suitable habitat. Expansion of macrophyte coverage can also be inferred from the increased accumulation rates of macrophyte remains observed in this period. Moreover, a gradual but steady decline in sediment $\mathrm{C}: \mathrm{N}$ ratio (mass) from 17 to 13.5 since AD 1905 in STE01 (27 cm, Fig. 7), indicates a higher relative contribution of organic matter originating from aquatic vegetation (Meyers 1994).

In contrast to many Scandinavian and northwestern European lakes, both the diatom assemblages of Steigatjørna and its stable inferred $\mathrm{pH}$ values over the past two centuries provide no evidence for major acidification (or subsequent liming) since the onset of the industrial revolution, despite deposition of acidifying substances in the region. Local presence of
Ca-rich anorthosite bedrock in the catchment area may have buffered some of the acid deposition, protecting the lake from acidification, without having a major alkalinization effect on the lake water. Similarly, liming of the pastures to improve soil conditions in the watershed could have provided additional buffering capacity.

Elodeid macrophyte appearance

Based on the diatom-inferred $\mathrm{pH}$ and TP (Fig. 7), the appearance of $C$. hamulata in the 1970 s and its expansion in the 1990s in lake Steigatjørna cannot be explained by acidification and/or phosphorus enrichment of the lake.

Although there are no strong indications that nitrogen levels increased in lake Steigatjørna during the past few decades, elevated nitrogen availability is not ruled out as a cause for the appearance and proliferation of $C$. hamulata. The potential linkage between increasing nitrogen levels and the appearance of $C$. hamulata in Steigatjørna, however, is weak because $C$. hamulata is able to grow well at very low nitrogen levels of $70 \mu \mathrm{g} \mathrm{l}^{-1}$, which is even lower than the nitrogen levels of $150 \mu \mathrm{g} \mathrm{l^{-1 }}$ found in nearby softwater lakes without $C$. hamulata (de Lyon and Roelofs 1986; Lucassen et al. 2009).

Because macrophyte production in softwater lakes is often carbon-limited (Murphy 2002) and the $\mathrm{CO}_{2}$ concentration in many soft water lakes without elodeids is low (Riera et al. 1999), it is likely that rising carbon and especially $\mathrm{CO}_{2}$ availability is of great importance for the appearance of the elodeid C. hamulata. During periods of high photosynthetic activity, the uptake of $\mathrm{CO}_{2}$ might result in very low $\mathrm{CO}_{2}$ levels in the water, $\leq 440 \mu \mathrm{g}^{-1}(100 \mu \mathrm{g}$ $\mathrm{CO}_{2}=2.27 \mu \mathrm{mol}$ ) (Robe and Griffiths 1992). Such low $\mathrm{CO}_{2}$ concentrations are insufficient to sustain the growth of $C$. hamulata, as has been shown experimentally (Spierenburg et al. 2009, 2010). Callitriche hamulata needed $\mathrm{CO}_{2}$ concentrations of $2,200 \mu \mathrm{g}^{-1}$ to show positive growth and $>4,400 \mu \mathrm{g} \mathrm{CO}_{2} 1^{-1}$ to approach maximal growth rates. The in situ $\mathrm{CO}_{2}$ values in Steigatjørna in 2006 were measured during midday, when the $\mathrm{CO}_{2}$ levels were commonly at their lowest concentrations due to uptake by primary producers. Still, the concentrations were above or around the thresholds for the survival of $C$. hamulata 
(Table 1). The $\mathrm{CO}_{2}$ levels during night and early morning are expected to be higher, thus enabling C. hamulata to thrive in Steigatjørna.

Lake water $\mathrm{CO}_{2}$ levels in Steigatjørna may have increased due to increasing DOC inputs to the lake, followed by degradation of DOC to $\mathrm{CO}_{2}$ (Cole et al. 2002). Enhanced input of DOC might be the result of liming of catchment pastures and a subsequent increase in soil decomposition rates. Furthermore, the observed rise in mean annual temperatures after the 1990s and changes in precipitation (Fig. 8) are likely to have increased terrestrial-derived DOC input. According to laboratory experiments, a small increase in $\mathrm{CO}_{2}$ levels is sufficient to sustain abundant elodeid growth in softwater lakes like Steigatjørna (Spierenburg et al. 2009, 2010) and trigger the invasion and expansion of $C$. hamulata at the expense of isoetid macrophytes.

Finally, in the late 1970s, part of the road along the eastern shore slid into the lake (Statens Vegvesen, pers. commun.), which is not only reflected by a decrease in the ${ }^{210} \mathrm{~Pb}$ activity at $10 \mathrm{~cm}$ (Fig. 2), but also by a marked decrease in diatom (Fig. 6) and pollen accumulation rates (Fig. 3), a sudden decrease in organic matter content and $\mathrm{C}: \mathrm{N}$ ratio, as well as high percentages of $\mathrm{Si}, \mathrm{Al}$, and $\mathrm{Fe}$ in the sediment (Fig. 7). This event mainly caused the eastern part of the basin to become substantially shallower, and buried the standing stock of macrophytes. This disturbance might have helped the initial invasion of $C$. hamulata, by releasing the plants from competition with isoetids, changing sediment chemistry, and temporarily increasing nutrient and carbon levels in the lake water.

In conclusion, this study showed that $C$. hamulata appeared locally and became the dominant species in a softwater lake, resulting in a decline in Isoëtes. Despite the fact that the appearance and expansion of $C$. hamulata in the recent past is not completely understood, we were able to use multiple sediment proxies to rule out phosphorus enrichment and acidification as drivers for this process. Instead, we argue that carbon enrichment, possibly combined with rising nitrogen levels in the lake water, made the appearance of lush $C$. hamulata vegetation possible. Effects of such carbon enrichment should be taken into account for the protection and management of softwater lakes.
Acknowledgments The authors thank Hanneke Bos for her help with plant macrofossil analyses, Walter Finsinger for help with pollen identification, and Emiliya Kirilova for help with diatom analyses. We are also grateful to two anonymous reviewers and Mark Brenner for their constructive comments and suggestions. This study was financed by the Centre for Wetland Ecology (CWE) and is Netherlands Research School of Sedimentary Geology (NSG) publication no 20100701.

Open Access This article is distributed under the terms of the Creative Commons Attribution Noncommercial License which permits any noncommercial use, distribution, and reproduction in any medium, provided the original author(s) and source are credited.

\section{References}

Appleby PG (2001) Chronostratigraphic techniques in recent sediments. In: Last WM, Smol JP (eds) Tracking environmental change using lake sediments. Volume 1: basin analysis, coring and chronological techniques. Kluwer, Dordrecht, pp 171-203

Battarbee RW (1973) A new method for the estimation of absolute microfossil numbers, with reference especially to diatoms. Limnol Oceanogr 18:647-653

Beijerinck W (1976) Zadenatlas der Nederlandsche Flora. Backhuys \& Meesters, Amsterdam, p 316

Bennett KD, Willis KJ (2001) 2. Pollen. In: Smol JP, Birks HJB, Last WM (eds) Tracking environmental change using lake sediments. Volume 3: terrestrial, algal and siliceous indicators. Kluwer, Dordrecht, pp 5-32

Bennion H (1994) A diatom-phosphorus transfer-function for shallow, eutrophic ponds in southeast England. Hydrobiologia 275:391-410

Bennion H, Appleby PG, Phillips GL (2001) Reconstructing nutrient histories in the Norfolk Broads, UK: implications for the role of diatom-total phosphorus transfer functions in shallow lake management. J Paleolimnol 26:181204

Berggren G (1969) Atlas of seeds and small fruits of Northwest-European plant species, part 2 Cyperaceae. Swedisch Natural Science Research Council, Stockholm

Berggren G (1981) Atlas of seeds and small fruits of Northwest-European plant species, part 3 Salicaceae-Cruciferae. Swedish Museum of natural History, Stockholm

Berthet P, Lecocq M (1977) Morphologie sporale des espèces françaises du genre Isoetes L. Pollen Spores 19:329-359

Beug H-J (2004) Leitfaden der Pollenbestimmung für Mitteleuropa und angrenzende Gebiete. Verlag Dr. Friedrich Pfeil, München

Birks HH, Birks HJB (2006) Multi-proxy studies in palaeolimnology. Veg Hist Archaeobot 15:235-251

Cameron NG (1995) The representation of diatom communities by fossil assemblages in a small acid lake. J Paleolimnol 14:185-223

Cappers RTJ, Bekker RM, Jans JEA (2006) Digital seed atlas of the Netherlands (in Dutch). Barkhuis Publishing \& Groningen University Library, Groningen 
Chen DX, Coughenour MB (1996) A mechanistic model for submerged aquatic macrophyte photosynthesis: Hydrilla in ambient and elevated CO2. Ecol Model 89:133-146

Chen GJ, Dalton C, Leira M, Taylor D (2008) Diatom-based total phosphorus (TP) and $\mathrm{pH}$ transfer functions for the Irish Ecoregion. J Paleolimnol 40:143-163

Cole JJ, Carpenter SR, Kitchell JF, Pace ML (2002) Pathways of organic carbon utilization in small lakes: results from a whole-lake 13C addition and coupled model. Limnol Oceanogr 47:1664-1675

de Lyon MJH, Roelofs JGM (1986) Waterplanten in relatie tot waterkwaliteit en bodemgesteldheid (in Dutch). Nijmegen University, Nijmegen

EDDI (2009) European Diatom Database. Newcastle University, Newcastle

Ellenberg H, Weber HE, Düll R, Wirth V, Werner W, Paulissen D (1991) Zeigerwerte von Pflanzen in Mitteleuropa. Scr Geobot 18:1-248

Evans CD, Monteith DT, Cooper DM (2005) Long-term increases in surface water dissolved organic carbon: observations, possible causes and environmental impacts. Environ Pollut 137:55-71

Faegri K, Iversen J (1989) Textbook of pollen analysis. Wiley, Chichester

Grahn O (1977) Macrophyte succession in Swedish lakes caused by deposition of airborne acid substances. Water Air Soil Pollut 7:295-305

Heiri O, Lotter AF, Lemcke G (2001) Loss on ignition as a method for estimating organic and carbonate content in sediments: reproducibility and comparability of results. J Paleolimnol 25:101-110

Hudson JJ, Dillon PJ, Somers KM (2003) Long-term patterns in dissolved organic carbon in boreal lakes: the role of incident radiation, precipitation, air temperature, southern oscillation and acid deposition. Hydrol Earth Syst Sci $7: 390-398$

Juggins S (2007) C2, Software for ecological and palaeoecological data analysis and visualisation, User guide Version 1.5. School of Geography, Politics \& Sociology, Newcastle University, Newcastle

Keeley JE (1998) CAM photosynthesis in submerged aquatic plants. Bot Rev 64:121-175

Krammer K, Lange-Bertalot H (1999a) Bacillariophyceae. 1. Teil: Naviculaceae. Spektrum Akademischer Verlag $\mathrm{GmbH}$, Heidelberg-Berlin

Krammer K, Lange-Bertalot H (1999b) Bacillariophyceae. 2. Teil: Bacillariaceae, Epithemiaceae, Surirellaceae. Spektrum Akademischer Verlag GmbH, Heidelberg-Berlin

Krammer K, Lange-Bertalot H (2000) Bacillariophyceae. 3. Teil: Centrales, Fragilariaceae, Eunotiaceae. Spektrum Akademischer Verlag GmbH, Heidelberg-Berlin

Krammer K, Lange-Bertalot H (2004) Bacillariophyceae. 4. Teil: Achnanthaceae, Kritische Ergänzungen zu Achnanthes s.l., Navicula s.str., Gomphonema. Spektrum Akademischer Verlag GmbH, Heidelberg-Berlin

Larssen T, Høgåsen T (2003) Tålergrenser og overskridelser av tålergrenser i Norge. Norsk Institutt for vannforskning, Oslo

Lotter AF (2003) Multi-proxy climatic reconstructions. In: MacKay A, Battarbee R, Birks J, Oldfield F (eds) Global change in the holocene. Arnold, London, pp 373-383
Lowe RL (1974) Environmental requirements and pollution tolerance of freshwater diatoms. National Environmental Research Center, Cincinnati

Lucassen ECHET, Bobbink R, Oonk MMA, Brandrud TE, Roelofs JGM (1999) The effects of liming and reacidification on the growth of Juncus bulbosus: a mesocosm experiment. Aquat Bot 64:95-103

Lucassen ECHET, Spierenburg P, Fraaije RGA, Smolders AJP, Roelofs JGM (2009) Alkalinity generation and sediment $\mathrm{CO}_{2}$ uptake influence establishment of Sparganium angustifolium in softwater lakes. Freshw Biol 54:2300-2314

Madsen TV, Maberly SC, Bowes G (1996) Photosynthetic acclimation of submersed angiosperms to $\mathrm{CO}_{2}$ and $\mathrm{HCO}_{3}$. Aquat Bot 53:15-30

Martin AC, Barkley WD (1961) Seed identification manual. University of California Press, Berkeley

MET (2009) eKlima. Norwegian Meteorological Institute, Oslo

Meyers PA (1994) Preservation of elemental and isotopic identification of sedimentary organic-matter. Chem Geol 114:289-302

Moore PD, Webb JA, Collinson ME (1991) Pollen analysis. Blackwell Scientific Publications, Oxford

Murphy KJ (2002) Plant communities and plant diversity in softwater lakes of northern Europe. Aquat Bot 73:287-324

Paillard D, Labeyrie L, Yiou P (1996) Macintosh program performs time-series analysis. Eos Trans AGU 77:379

Renberg I, Hultberg H (1992) A paleolimnological assessment of acidification and liming effects on diatom assemblages in a Swedish lake. Can J Fish Aquat Sci 49:65-72

Renberg I, Korsman T, Anderson NJ (1993) A temporal perspective of lake acidification in Sweden. Ambio 22:264-271

Riera JL, Schindler JE, Kratz TK (1999) Seasonal dynamics of carbon dioxide and methane in two clear-water lakes and two bog lakes in northern Wisconsin, USA. Can J Fish Aquat Sci 56:265-274

Robe WE, Griffiths H (1992) Seasonal variation in the ecophysiology of Littorella uniflora (L.) Ascherson in acidic and eutrophic habitats. New Phytol 120:289-304

Roelofs JGM (1983) Impact of acidification and eutrophication on macrophyte communities in soft waters in The Netherlands I. Field observations. Aquat Bot 17:139-155

Roelofs JGM, Brandrud TE, Smolders AJP (1994) Massive expansion of Juncus bulbosus L. after liming of acidified SW Norwegian lakes. Aquat Bot 48:187-202

Rühland KM, Smol JP (2002) Freshwater diatoms from the Canadian arctic treeline and development of paleolimnological inference models. J Phycol 38:249-264

Sayer CD (2001) Problems with the application of diatom-total phosphorus transfer functions: examples from a shallow English lake. Freshw Biol 46:743-757

Sayer C, Roberts N, Sadler J, David C, Wade PM (1999) Biodiversity changes in a shallow lake ecosystem: a multi-proxy palaeolimnological analysis. J Biogeogr 26:97-114

Schotsman HD (1954) A taxonomic spectrum of the section Eu-Callitriche in the Netherlands. Acta Bot Neerl 3:313-384

Spierenburg P, Lucassen ECHET, Lotter AF, Roelofs JGM (2009) Could rising aquatic carbon dioxide concentrations favour the invasion of elodeids in isoetid-dominated softwater lakes? Freshw Biol 54:1819-1831 
Spierenburg P, Lucassen ECHET, Lotter A, Roelofs JGM (2010) Competition between isoetids and invading elodeids at different concentrations of aquatic carbon dioxide. Freshw Biol 55:1274-1287

ter Braak CJF, Juggins S (1993) Weighted averaging partial least squares regression (WA-PLS): an improved method for reconstructing environmental variables from species assemblages. Hydrobiologia 269(270):485-502

van Dam H, Mertens A, Sinkeldam J (1994) A coded checklist and ecological indicator values of freshwater diatoms from the Netherlands. Neth J Aquat Ecol 28:117-133
Wetzel RG (2001) Limnology, lake and river ecosystems. Academic Press, San Diego

Wolfe AP, Baron JS, Cornett RJ (2001) Anthropogenic nitrogen deposition induces rapid ecological changes in alpine lakes of the Colorado Front Range (USA). J Paleolimnol 25:1-7 